\title{
SHEAR RESPONSE OF LARGE R. C. BEAMS PROVIDED WITH SIDE BARS UNDER REPEATED LOADING
}

\author{
Yehia A. Hassanean \\ Civil Engineering Department, Faculty of Engineering, Assiut University, \\ Assiut, Egypt, yehiamk@yahoo.com
}

(Received June 1, 2006 Accepted June 22, 2006)

\begin{abstract}
Cracks of reinforced concrete beams may be expected under a certain service load because of low tensile strength of concrete. In other hand, cracking of reinforced concrete structures is considered undesirable, not only aesthetic reasons, but also because it adversely affects durability and leads to corrosion of embedded reinforcement. So distribution of longitudinal reinforcement is required along the side faces of large concrete beams to control cracking. Most of national codes recommended provision of large beams with side bars added at both sides of the beam cross-sections. Some of these bars may lie at compression or tension zones according to their arrangement. These bars contribute to the overall shear strength and useful in the design of the reinforced concrete cross-sections. The aim of this work is to study the response of short beams as affected by side bars location, amount of area and arrangement along the side face of the beams and subjected to repeated loading. For this purpose an experimental program was set up and tests on ten large reinforced concrete short beams were carried out under transverse service repeated loading followed by static loading up to failure. The patterns of cracks were traced, the modes of failure were observed, the crack widths were measured, and the deformations were recorded as well as both cracking and ultimate loads were also measured. The results show that providing side bars to short beams have a significant and considerable effect on shear response of such beams and hence it should be recommended to be taken into account in designing of such beams.
\end{abstract}

KEYWORDS: Side face reinforcement, repeated loading, Shear span to depth ratio, Deformation.

\section{INTRODUCTION}

Cracking is one of the important serviceability limit state to be considered in the design of reinforced concrete members. First crack strength should be estimated accurately by giving consideration to the variability in dimensions and strength of materials, thus there is a need to consider the randomness of the cracking strength of the reinforced concrete. Cracks in the large concrete beams are caused primarily by flexural or shear stresses, but also, to some extent by restrained shrinkage. Shrinkage 
often causes a considerable deformation as well as appreciable stress change in concrete structures.

Many factors affect on crack width in reinforced concrete beams as grade and quality of concrete, space between main steel reinforcement, the stress in main steel, concrete cover, distance from crack to neutral axis and area of concrete around each reinforcing bar. The cracks can be controlled by decreasing of space between main steel bars, diameter of steel bars, maximum stress in main steel and concrete cover thickness.

The arrangement of longitudinal reinforcement is required along the side faces of large concrete beams to control cracking, [1 to 4]. Large amount of side-faces reinforcement leads to smaller cracks. Steel fiber was also beneficial in controlling diagonal cracks at higher shear stress value, [4]. However controlling diagonal cracks is a more complicated phenomenon that depends not only on the amount and arrangement of longitudinal reinforcement but also on the amount of transverse reinforcement and the shear stress level as well as on the concrete cover to the reinforcement, [4]. So, the national codes recommended many rules to control the cracks width.

The ECCS 203-2001 code, [5], recommended that, for beams with total depth higher than $700 \mathrm{~mm}$, side bars must be provided with minimum area $8 \%$ of the tension reinforcement and the distance between side bars must not exceed $300 \mathrm{~mm}$. The German Code Din 1045 Absch 21.1.2, sited from [4], requires the same amount of side bars that recommended by ECCS 203-2001 code's [3].

The Canadian concrete code CSA A23.3, sited from [4], requires side face skin reinforcement in beams with overall depths greater than $75 \mathrm{~cm}$. For exterior exposures, a reinforcement ratio of $1.0 \%$ required by the Canadian concrete code in the outer skin, which is assumed to be twice the concrete cover plus the diameter of side bar, thick on each side of the beam web. The Canadian Highway Bridge code CHBDC, sited from [4], requires reinforcement with an area equal to $1.0 \%$ of the total web area, distributed over $70 \%$ of the web depth, which results in a minimum of $1.4 \%$ longitudinal reinforcement in effective zone. In calculating the required area of reinforcement, the width of the web need not be taken greater than $25 \mathrm{~cm}$ as the side face reinforcement is assumed to act as skin reinforcement in wider members.

For controlling the cracks that initiated by shrinkage, the ACI 318 Building Code [6], and AASHTO Bridge code, requires special side face reinforcement in all beams deeper than $91.4 \mathrm{~cm}$ (36 inch). In earlier edition of the Code this amount of side reinforcement was assumed to be taken $10 \%$ from the tension reinforcement. In 1989 edition, the ACI Code adopted procedure based on a proposal from Frantz and Breen [7]. They proposed that the amount of side face reinforcement in large beams be independent of the amount of flexural reinforcement and depend primarily on the member depth, but also on the clear concrete cover to the side face reinforcement and the diameter of the side face reinforcing bars. The ACI 318 Building Code [6], adopted a procedure in which the amount of side face reinforcement depends only on the member depth, except that it need not exceed one half of the flexural tension reinforcement. The current AASHTO Bridge code requirements are similar to the 
current ACI Building code requirements and both are similar to Frantz and Breen [6], as shown in Fig. 1.

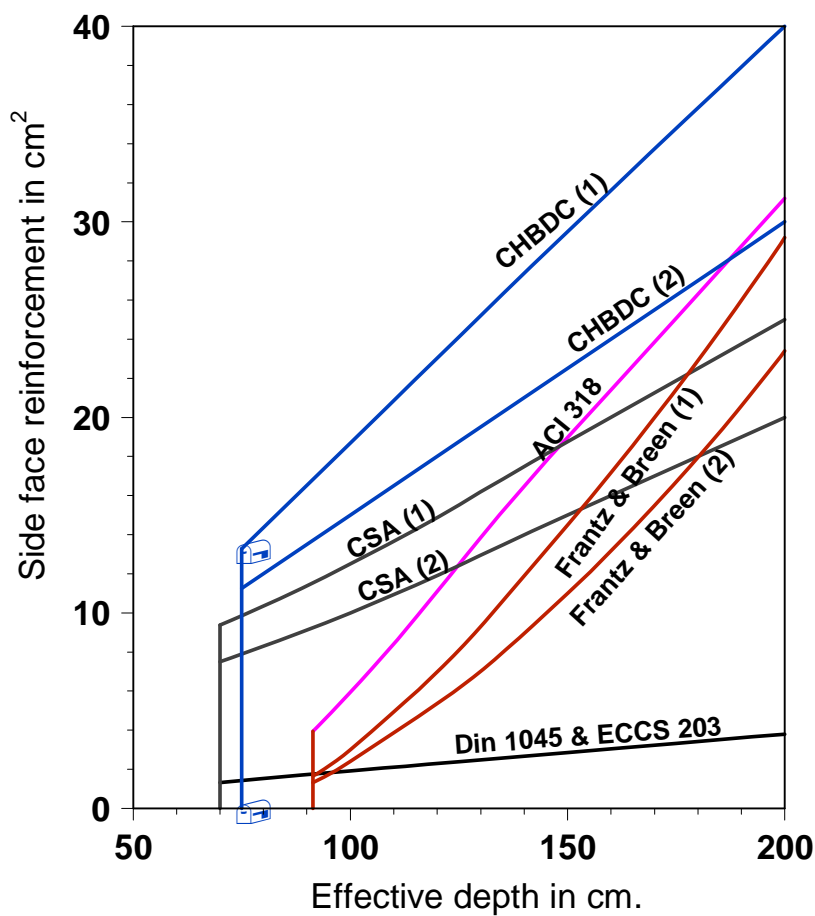

CHBDC (1) for $b_{w}=20 \mathrm{~cm}$

CHBDC (2) for $b_{w}=15 \mathrm{~cm}$

CSA (1) for $(2 c+d b)=12.5 \mathrm{~cm}$

CSA (2) for $(2 \mathrm{c}+\mathrm{db})=10.0 \mathrm{~cm}$

Din 1045 for $\mu=1.0 \%$

ECCS 203 for $\mu=1.0 \%$

Frantz \& Breen for :

$(2 \mathrm{c}+\mathrm{db})=12.5 \mathrm{~cm}$

Frantz \& Breen for:

$(2 \mathrm{c}+\mathrm{db})=10.0 \mathrm{~cm}$

Where: $\quad c=$ concrete cover;

$\mathrm{d}_{\mathrm{b}}=$ side bar diameter

Fig. 1: Comparison of different codes requirements for side reinforcement.

The British Code CP114 [8], recommended that to control the crack width skin reinforcement must be distributed over $2 / 3$ the depth of the beam for beams having depth higher than $70 \mathrm{~cm}$. The diameter of the side bars should not be less than $\sqrt{S_{b} b / f_{y}}$, where:

$S_{b} \quad$ distance between side bars,

$b \quad$ beam width, and;

$f_{y} \quad$ yield strength of side bar reinforcement.

The diameter of the side bars must not be less than 0.45 times the diameter of the largest bar in the section or $\sqrt{S_{b} f_{y} / b}$. A comparison between the requirements of different codes for side reinforcement is given in Fig. 1. It is obvious from the figure that there are considerable differences how much side face reinforcement is appropriate.

Ultimate strength criteria alone may not be a sufficient basis for design for shear, as crack widths at service loads must be controlled. The ACI 318 building code [6], evaluates the crack width in both cases, vertical in flexural beams and inclined cracks in shear beams. For flexural beams the following equation is considered: 
$w_{\max }=0.076 \sqrt[3]{t_{b} A} \frac{h_{2}}{h_{1}} f_{s} \times 10^{6}$,

For internal element : $\sqrt[3]{t_{b} A} \frac{h_{2}}{h_{1}} \geq 175$ and $w_{\max } \prec 0.40 \mathrm{~mm}$

For external element : $\sqrt[3]{t_{b} A} \frac{h_{2}}{h_{1}} \geq 145$ and $w_{\max } \prec 0.33 \mathrm{~mm}$

For shear beams the following equation is considered:

$w_{\text {max }}=\frac{s \sin \alpha}{10^{6} r\left(f_{c}^{\prime}\right)^{1 / 3}} \cdot \frac{V-V_{c r}}{b d}$

Where:

$w_{\max }$ maximum crack width in inch;

$t_{b} \quad$ distance from extreme tension fiber to the center of the adjacent bar in inch;

A average effective area of concrete in tension around each reinforcing bar in inch $^{2}$;

$f_{s} \quad$ steel stress in psi;

$h_{1} \quad$ distance from concrete of the tension steel to the neutral axis in inch;

$h_{2} \quad$ distance from extreme tension fiber to the neutral axis in inch;

$\mathrm{s} \quad$ spacing of shear reinforcement measured in direction of span in inch;

$\alpha \quad$ angle between the shear reinforcement and direction of span in degree;

$V \quad$ shear force in Ib;

$V_{c r} \quad$ shear force causing shear cracking in Ib;

$r \quad$ ratio of shear reinforcement;

$f_{c}^{\prime} \quad$ cylindrical concrete compressive strength in psi, and;

$d \quad$ effective depth in inch.

Side bars arrangement not only to resist shrinkage but also to contribute in the overall resistance of such beams, Zainab et-al [9]. They study the contribution of shrinkage bars on the behavior of reinforced concrete beams under static loading. This paper summarizes the results of an experimental program about the contribution of the side bars in the shear response and behavior of the short reinforced concrete beams subjected to repeated loading. For this aim an experimental program of ten large reinforced concrete beams provided with side bars were prepared and tested under one point repeated loading. The main variables that considered in this work are the location of side bars to tension steel, amount of area of side bars and arrangement of the side bars along the height of each side of the beam depth. The considered area of side bars in this study was varied from zero (beams without side bars) to five times the area that recommended in the Egyptian ECCS 203-2001 code, [5]. 


\section{TEST PROGRAM, FABRICATION OF THE TESTED BEAMS AND TEST PROCEDURE}

The experimental program was carried out in reinforced concrete laboratory, Assiut University. Through testing ten beams, the effects of existing side reinforcement on the shear response of R.C beams cross-section under one point repeated loading were studied. The main variables taken into consideration in this study were arrangement of side bars along side face of the beam, location of side bars with respect to tension steel and the amount of area of side bars.

The testing program was designed to investigate the influence of the previous variables on the reinforced concrete short beams failed mainly due to shear stresses $(\mathrm{a} / \mathrm{d}=1.50)$, under repeated loading. All tested beams were having $70 \mathrm{~cm}$ total depth, $12 \mathrm{~cm}$ beam width, $4 \phi 19$ tension reinforcement, $2 \phi 13$ top reinforcement and $\phi 6$ each $15 \mathrm{~cm}$ stirrups. Beam $B_{1}$ and beam $B_{2}$ were taken as reference beams (without side bars). In the rest beams side bars were arranged in different locations as shown in Fig. 2.

Concrete mix was designed to produce a concrete having 28-days cubic strength of about $27.5 \mathrm{MPa}$, this mix was used for all tested beams. The constituent materials were:

a- Ordinary Portland cement.

b- Local gravel of $10 \mathrm{~mm}$ maximum nominal size, 2.65 specific gravity and $1.68 \mathrm{t} / \mathrm{m}^{3}$ volume weight.

c- Local sand of medium grading, 2.50 specific gravity and $1.56 \mathrm{t} / \mathrm{m}^{3}$ volume weight.

d- Potable water was used for mixing and curing.

e- Plain bars of nominal mild steel were used as reinforcing bars and stirrups. The used steel confirms with the limits of ECCS 203-2001, see Table 2.

Table 1: Details of the Tested Beams.

\begin{tabular}{|c|c|c|c|c|c|}
\hline Beam No. & $f_{c u}(\mathrm{MPa})$ & Side Bars & $\mu^{\prime} \%$ & $\mu_{s s} \%$ & $\Psi$ \\
\hline $\mathrm{B}_{1}$ & 29.5 & - & 0 & 0 & 0 \\
\hline $\mathrm{B}_{2}$ & 29.0 & - & 0 & 0 & 0 \\
\hline $\mathrm{B}_{3}$ & 28.4 & $2 \phi 13$ & 0.70 & 0.235 & 0.117 \\
\hline $\mathrm{B}_{4}$ & 28.1 & $4 \phi 10$ & 0.83 & 0.277 & 0.139 \\
\hline $\mathrm{B}_{5}$ & 28.2 & $6 \phi 8$ & 0.79 & 0.266 & 0.133 \\
\hline $\mathrm{B}_{6}$ & 28.7 & $2 \phi 13$ & 0.70 & 0.235 & 0.047 \\
\hline $\mathrm{B}_{7}$ & 28.0 & $2 \phi 13$ & 0.70 & 0.235 & 0.094 \\
\hline $\mathrm{B}_{8}$ & 28.5 & $2 \phi 13$ & 0.70 & 0.235 & 0.141 \\
\hline $\mathrm{B}_{9}$ & 28.3 & $2 \phi 13$ & 0.70 & 0.235 & 0.188 \\
\hline $\mathrm{B}_{10}$ & 28.5 & $6 \phi 10$ & 1.27 & 0.416 & 0.208 \\
\hline
\end{tabular}

Where:

$f_{c u} \quad$ cube compressive strength, in $\mathrm{MPa}$;

$\mu^{\prime} \quad$ skin reinforcement ratio $=$ total area of side bars $/ 2\left(2 c+d_{b}\right) d$

c concrete cover;

$\mathrm{d}_{\mathrm{b}} \quad$ side bar diameter; 
$\mu_{s s} \quad$ total area of side bars/ total area of tension steel;

$\Psi \quad$ side bar parameter $=\sum A_{s s} y / A_{s} d$

$A_{s s} \quad$ area of one row of side bars;

$y \quad$ distance from side bars row to center of tension steel; and

$A_{s} \quad$ area of tension steel.

The concrete was mixed mechanically and cast in steel forms. Control specimens including cubes of $15 \mathrm{~cm}$ side length were cast from each mix. The beams and control specimens were sprayed with fresh water two times daily until the day before testing; all beams were tested at age of 28 days. Complete details of the tested beams are given in Table 1 and Fig. 2.

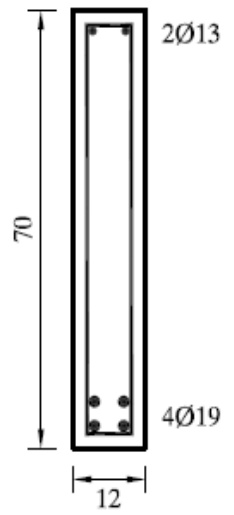

B1

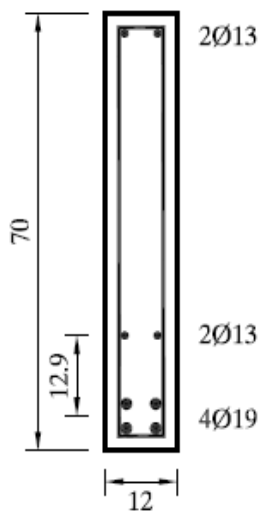

B6

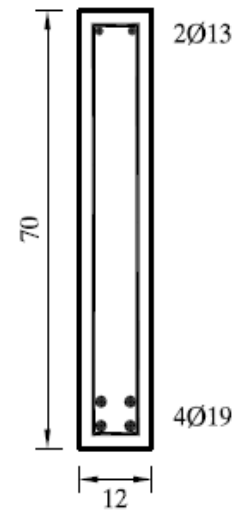

B2

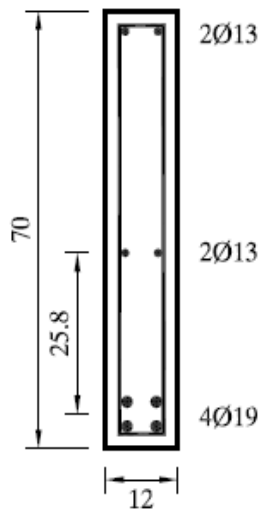

B7

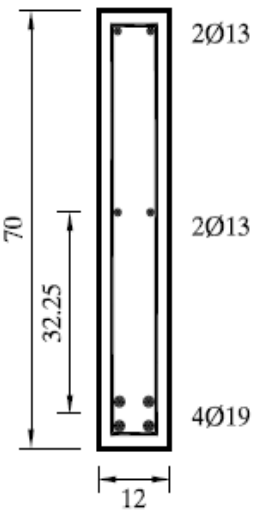

B3

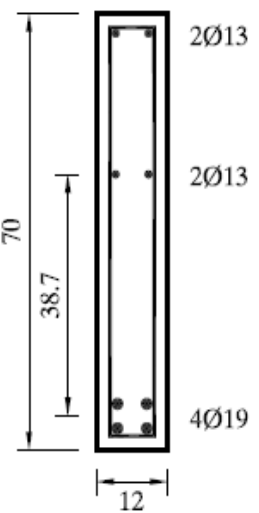

B8

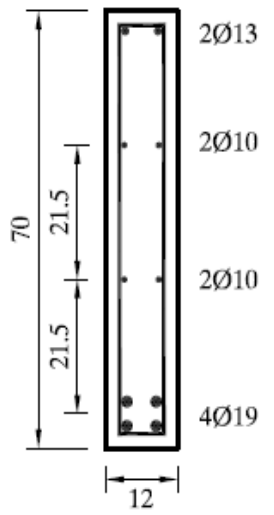

B4

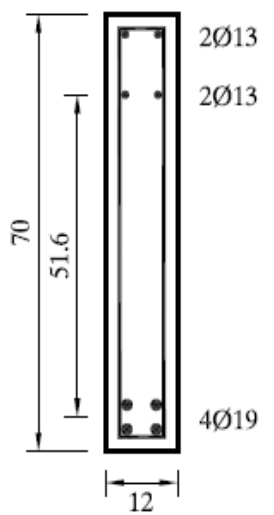

B9

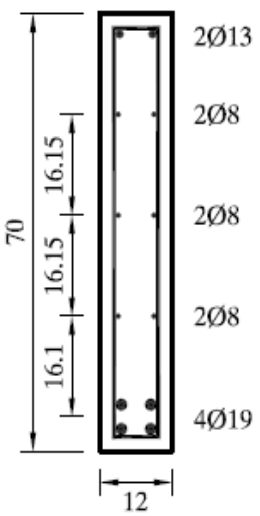

B5

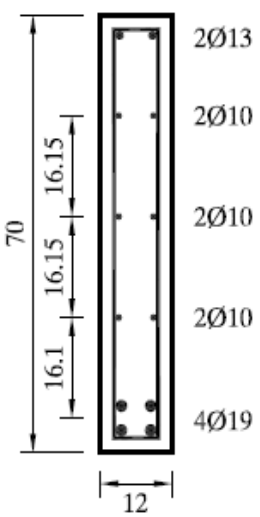

B10

Fig. 2: Details of the cross-sections of tested beams.

The beams were tested over a freely simply supported span of $194 \mathrm{~cm}$ under one point loading. The load was applied in increments, before cracking each increment was 1.0 ton but after cracking each increment was 2.0 ton. The load was kept constant between two successive increments for about five minutes. During this period the cracks were traced, the mid span deflection and strain in both steel and concrete were 
recorded. The Beam $B_{1}$ tested under static loading while the other beams were tested under repeated loading. The beams loaded until $70 \%$ of the ultimate static load of reference beam $\mathrm{B}_{1}$, (25 ton), then the load is removed gradually until zero load, after that the beams loaded gradually up to $70 \%$ of the ultimate load of $\mathrm{B}_{1}$. Then the dynamic load is started with 500 cycle/minute with stroke $0.20 \mathrm{~mm}$ up to one million cycles. Then the load is removed gradually until zero load, after that the beam is loaded statically up to failure. The scheme of the loading is shown in Fig. 3.

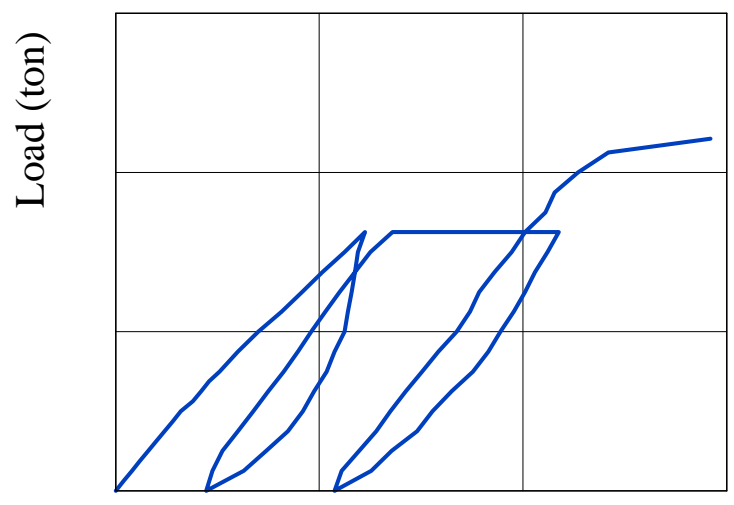

Deflection in $\mathrm{mm}$.

Fig. 3: Scheme of the loading.

Table 2: Mechanical properties of the used steel.

\begin{tabular}{|l|c|c|c|c|c|}
\hline Commercial diameter $(\mathbf{m m})$ & 6 & 8 & 10 & 13 & 19 \\
\hline Actual diameter $(\mathbf{m m})$ & 6.02 & 7.97 & 9.98 & 12.95 & 19.01 \\
\hline Yield stress $\mathbf{( M P a )}$ & 259.8 & 262.1 & 283.4 & 277.5 & 269.8 \\
\hline Ultimate stress $\mathbf{( M P a )}$ & 383.6 & 392.4 & 401.3 & 396.2 & 389.7 \\
\hline \% of elongation & 24.7 & 25.2 & 23.6 & 26.1 & 26.7 \\
\hline
\end{tabular}

\section{RESULTS AND DISCUSSION}

Examination of the test results given in Tables 3, $\mathbf{4}$ and $\mathbf{5}$ as well as investigation of Fig. 5 to Fig. 8, declare the following:

\section{Pattern of Cracks, Mode of Failure and Width of cracks}

The first flexural and inclined cracks appeared at the same time in beams $B_{1}$ and $B_{2}$ (beams without side bars), also these crack are initiated in the same region. The first crack in beams without side bars was flexural crack while it was shear crack in beams provided with side bars. Meanwhile the flexural cracks stopped its propagation at certain height in beams provided with side bars. Then the inclined cracks firstly 
extended and secondly widened gradually upward toward the loading point and downward towards the bottom surface of the beam near the supports.

Comparison of pattern cracks of beams $\mathrm{B}_{1}$ without side bars, and tested under static loading with pattern of cracks of beam $\mathrm{B}_{2}$, without side bars and tested under repeated loading showed that the cracks width were higher in beams subjected to repeated loading than that subjected to static loading, see Fig. 4.

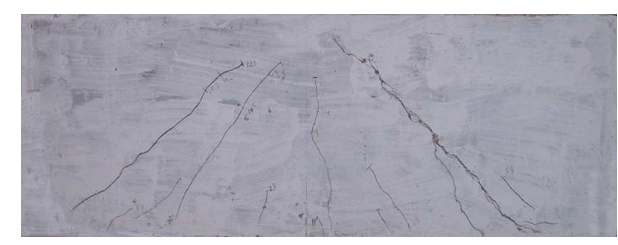

Pattern of cracks of beam $B_{1}$

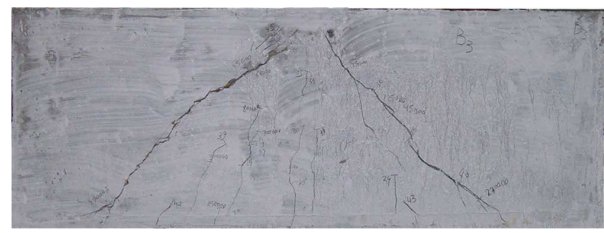

Pattern of cracks of beam $B_{3}$

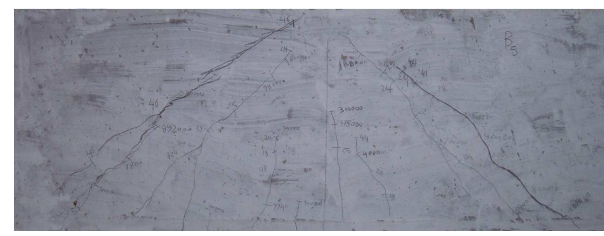

Pattern of cracks of beam $\mathrm{B}_{5}$

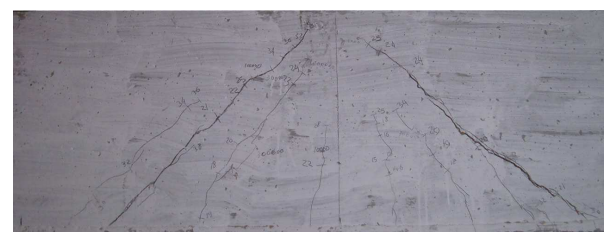

Pattern of cracks of beam $\mathrm{B}_{7}$

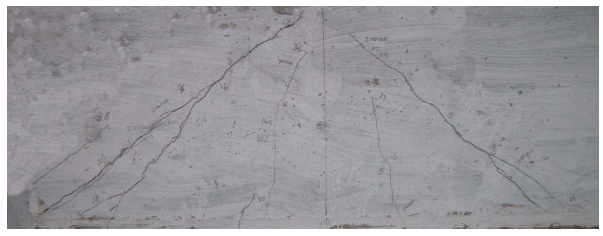

Pattern of cracks of beam $\mathrm{B}_{9}$

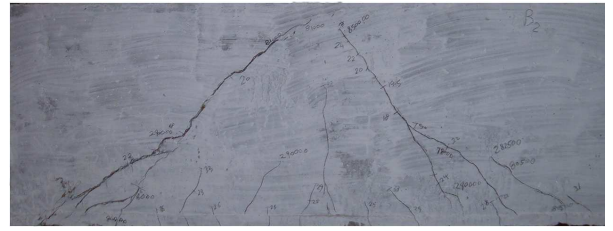

Pattern of cracks of beam $\mathrm{B}_{2}$

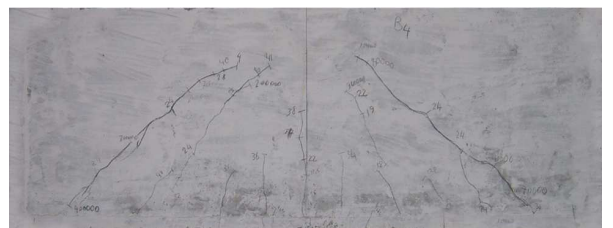

Pattern of cracks of beam $B_{4}$

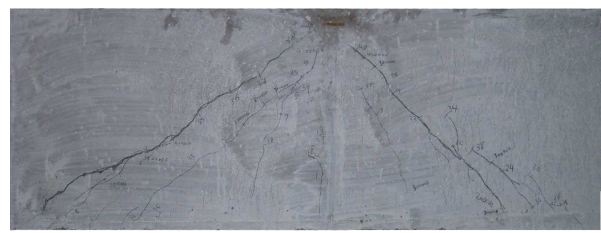

Pattern of cracks of beam $B_{6}$

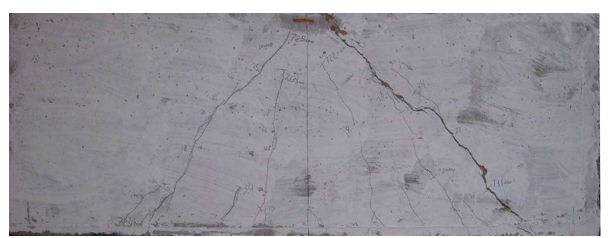

Pattern of cracks of beam $\mathrm{B}_{8}$

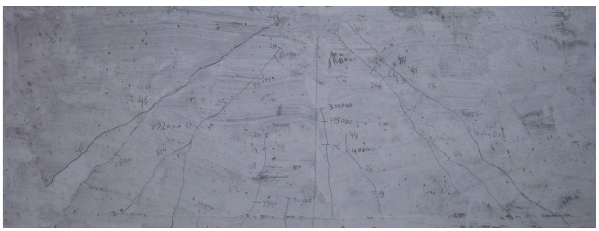

Pattern of cracks of beam $B_{10}$

Fig. 4: Patterns of cracks of the tested beams. 
Comparing pattern of cracks for beam $\mathrm{B}_{2}$ without side bars to pattern of cracks of beams $B_{3}, B_{4}$ and $B_{5}$ provided with $2 \phi 13,4 \phi 10$ and $6 \phi 8$ side bars respectively, showed that in beams having side bars the numbers of cracks were higher and the widths were lower. This observation was more clearly when the side bars were arranged in several rows. Meanwhile the widths of the cracks were higher when the side bars were provided in one row. Another observation is that the angles of inclination of major cracks were lower when the side bars were provided in several rows, see Table 3. When the side bars were located in one row, the distance from the tension reinforcement has a pronounced effect on the pattern of cracks. The number and width of cracks were increased as this distance increased.

The tested beams were subjected to high shear stresses with low flexural stresses; it is likely that the maximum principal tensile stress is located at the neutral axis level at an inclination of $45^{\circ}$; the resulting cracks were diagonal tension cracks.

Shear cracks extended upward to the neutral axis and some times into the compression zone. Presence of side bars prevents longitudinal splitting failures of compression struts. So, all the tested beams failed in shear by diagonal tension failure nearly along a line joining the support and the load. Providing the side bar reinforcement in the beam cross section provides additional restraining forces across the crack that reduce the crack width as shown in Table 3.

The crack widths of the tested beams were calculated by using equation 4 and presented in Table 3. The measured values of crack width of the beams provided with side bars distributed in several rows or in one row near the tension zone are lower than the crack width that calculated from equation 4 . The experimental crack width value was 0.42 of the calculated crack width of beams provided with five times the side bars area that recommended in ECCS 203. This ratio was 0.75 when the side bars were located at the middle of the section depth; this means that distribution of side bars in several rows decreased the crack width to $55 \%$.

Table 3. Test results of the tested beams.

\begin{tabular}{|c|c|c|c|c|c|}
\hline Beam No. & $\Psi$ & $w_{\text {exp }}$ & $w_{\text {eqn.(4) }}$ & $\theta^{O}$ & $\Delta_{l} \%$ \\
\hline$B_{1}$ & 0 & 3.00 & 2.76 & 44.3 & 1.09 \\
\hline$B_{2}$ & 0 & 3.20 & 2.94 & 46.7 & 1.09 \\
\hline$B_{3}$ & 0.117 & 2.85 & 3.79 & 44.3 & 0.75 \\
\hline$B_{4}$ & 0.139 & 2.0 & 3.72 & 42.2 & 0.54 \\
\hline$B_{5}$ & 0.133 & 1.6 & 3.78 & 41.2 & 0.42 \\
\hline$B_{6}$ & 0.047 & 1.75 & 3.51 & 38.6 & 0.50 \\
\hline$B_{7}$ & 0.094 & 2.65 & 3.82 & 44.8 & 0.69 \\
\hline$B_{8}$ & 0.141 & 2.85 & 3.63 & 44.8 & 0.79 \\
\hline$B_{9}$ & 0.188 & 3.10 & 3.18 & 44.1 & 0.97 \\
\hline$B_{10}$ & 0.208 & 1.45 & 3.86 & 40.8 & 0.38 \\
\hline
\end{tabular}

Where: $w_{\text {exp. }}$ maximum experimental crack width in $\mathrm{mm}$;

$\mathrm{W}_{\text {Eqn. (4) }}$ maximum crack width calculated based on Eqn. (4) in mm;

$\theta^{O} \quad$ angle of slope of major cracks with horizontal direction, and;

$\Delta_{1} \quad$ experimental crack width/ crack width calculated based on Eqn. (4); 
In Fig. 5 the relation between the ratio of side bars area to the area of side bars that recommended in ECCS 203 against the ratio between the experimental crack width and calculated crack width by using equation 4 is plotted. From this figure it is clear that the area of side bar has pronounced effect in the crack width and the crack width of the beams without side bars are higher than that calculated.

\section{Cracking and Ultimate Loads}

Regarding to the investigation of Fig. 6a to Fig. 6c and Table 4, the cracking load increases as the side bars were provided in the tested beams. The cracking load increases as the area of side bars increases or the side bars arrangement in several rows or in one row near the tension steel. When the side bars are located in one row the cracking load increases as the distance between the side bars and tension steel decreases. The maximum cracking loads were recorded for beams $\mathrm{B}_{5}, \mathrm{~B}_{6}$ and $\mathrm{B}_{10}$ that provided with side bars arrangement in three rows or in one row at distance 0.20 of the effective depth from the tension steel. The maximum increasing in cracking load was about $32 \%$ (beam $\mathrm{B}_{6}$ ). The increasing of cracking loads is mainly due to the fact that the existing of bars in the side face of the beam delayed the appearance of cracks and increasing the elastic stiffness of the cross section.

The cracking loads of the tested beams are calculated based in flexural cracking or inclined cracking by using the following ACI equations [6], and presented in Table 4.

$$
\begin{aligned}
& V_{c}=\left(1.90 \sqrt{f_{c}^{\prime}}+\frac{2500 \rho_{w} V_{u} d}{M_{u}}\right) b d \\
& M_{c r}=\frac{f_{c r t} I_{g}}{y_{t}} \\
& f_{c t r}=7.50 \sqrt{f_{c}^{\prime}}
\end{aligned}
$$

Where: $V_{c}$ cracking shear force;

$\rho_{w}$ percentage of main reinforcement;

$V_{u} \quad$ ultimate shear force;

$M_{c r}$ cracking bending moment;

$M_{u}$ ultimate bending moment;

$\mathrm{F}_{\mathrm{ctr}} \quad$ concrete tensile strength;

$I_{g} \quad$ gross moment of inertia, and;

$y_{t} \quad$ distance between the neutral axis and extreme tension fiber.

The flexural cracking loads were calculated taking into consideration the influence of side bars in the values of gross moment of inertia $\mathrm{I}_{\mathrm{g}}$. From Table 4 it is clear that the experimental cracking loads are higher than the calculated cracking loads. This is because the influence of existing side bars which delayed appearance of cracks.

The experimental values of ultimate loads are influenced by the studied parameters. From Table 4 it is clear that the ultimate loads are increased as the side bars are arranged in several rows or located in one row near the tension zone as well as increasing of side bar area. In general, this is because providing the beam with side bars affected the crack pattern and helps in arresting the growth of diagonal cracks and hence increasing the ultimate loads of the tested beams. 


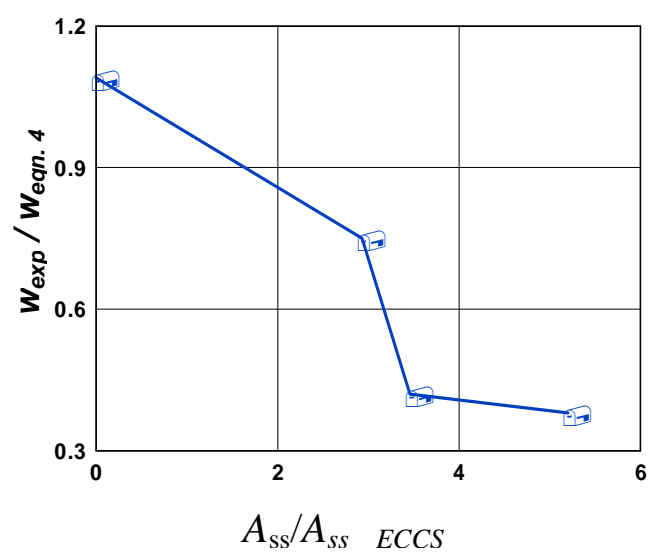

Fig. 5: The relation between ratio of area side bars to that recommended in ECCS 203 and the ratio of experimental to calculated crack width.

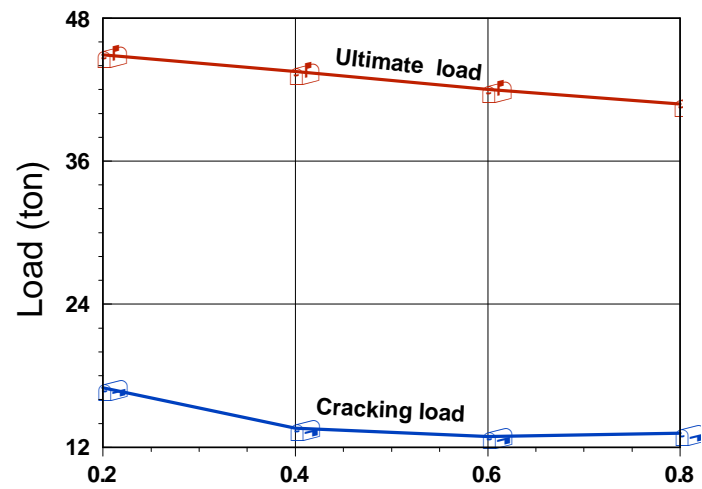

Distance from tension steel to effective depth.

Fig. 6b: Influence of position of side bars on cracking and ultimate loads.

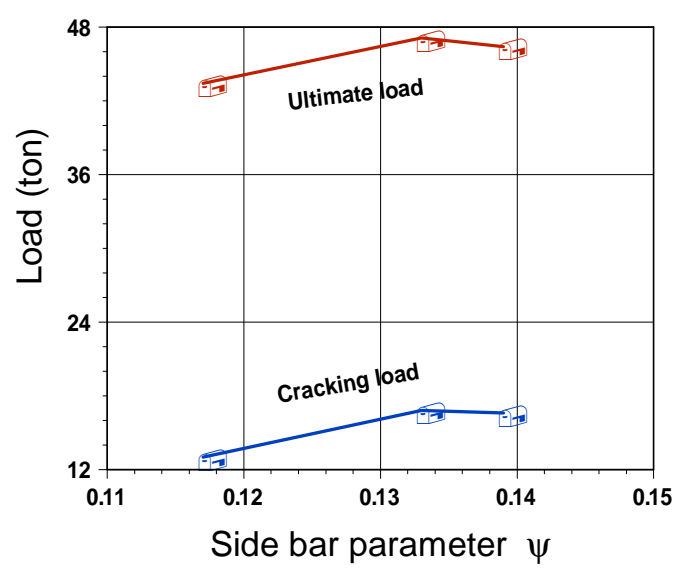

Fig. 6a: Influence of arrangement of bars on cracking and ultimate loads.

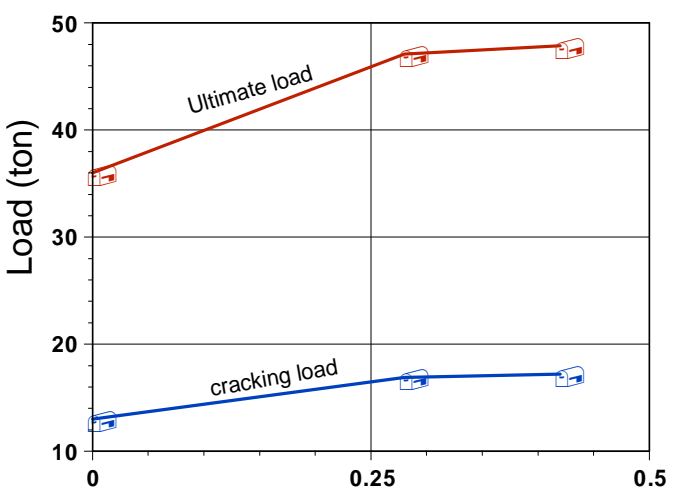

$\mathrm{A}_{\mathrm{ss}} / \mathrm{A}_{\mathrm{s}}$

Fig. 6c: Influence of area of side bar on cracking and ultimate loads.

Comparison of ultimate load of beam $\mathrm{B}_{2}$ and beam $\mathrm{B}_{1}$ show that the repeated loading has no tangible effect on the ultimate load. But with respect to the ultimate load, side bars which were arranged in three rows was the best situation; the ultimate loads of beam $\mathrm{B}_{5}$ and $\mathrm{B}_{10}$ were higher than the ultimate load of beam $\mathrm{B}_{2}$ by $31 \%$ and $35 \%$ respectively.

The position of the longitudinal side bars on the beam cross-section appeared to have a tangible effect on the ultimate load. Displacing the side bar toward the tension zone seemed to have increasing the ultimate load. The ultimate loads of beam $\mathrm{B}_{6}$ that provided by side bars in one row at distance from the tension steel equals to 0.20 of the effective beam depth were higher than that of beam $\mathrm{B}_{2}$ without side bars by $31.0 \%$. 
When the side bars displacing towards the compression zone, beams $\mathrm{B}_{8}$ and $\mathrm{B}_{9}$ decreased the cracked zone on the beam sides to the middle part between the tension tie reinforcement and two diagonal concrete struts. This leaded to strengthening diagonal strut and hence to an increase in the ultimate load.

Table 4. Cracking and ultimate loads of the tested beams.

\begin{tabular}{|c|c|c|c|c|c|c|c|c|}
\hline $\begin{array}{c}\text { Beam } \\
\text { No. }\end{array}$ & $\Psi$ & \multicolumn{3}{|c|}{ Cracking load (ton) } & $P_{u}$ & $\Delta_{2}$ & $\Delta_{3}$ & $\Delta_{4}$ \\
\cline { 3 - 6 } ton & & & & \\
\hline$B_{1}$ & 0 & 12.9 & 14.26 & 8.45 & 35.0 & 1.0 & 1.11 & 0.97 \\
\hline$B_{2}$ & 0 & 13.0 & 14.26 & 8.45 & 36.0 & 1.01 & 1.14 & 1.00 \\
\hline$B_{3}$ & 0.117 & 13.0 & 14.26 & 8.70 & 43.4 & 1.01 & 1.37 & 1.21 \\
\hline$B_{4}$ & 0.139 & 16.6 & 14.26 & 8.42 & 46.4 & 1.29 & 1.47 & 1.29 \\
\hline$B_{5}$ & 0.133 & 16.9 & 14.26 & 8.42 & 47.1 & 1.31 & 1.49 & 1.31 \\
\hline$B_{6}$ & 0.047 & 17.0 & 14.26 & 8.79 & 44.9 & 1.32 & 1.42 & 1.25 \\
\hline$B_{7}$ & 0.094 & 13.6 & 14.26 & 8.44 & 43.5 & 1.05 & 1.37 & 1.21 \\
\hline$B_{8}$ & 0.141 & 12.9 & 14.26 & 8.53 & 42.0 & 1.00 & 1.33 & 1.17 \\
\hline$B_{9}$ & 0.188 & 13.2 & 14.26 & 8.55 & 40.8 & 1.02 & 1.29 & 1.13 \\
\hline$B_{10}$ & 0.208 & 17.2 & 14.26 & 8.61 & 48.7 & 1.33 & 1.54 & 1.35 \\
\hline
\end{tabular}

$P_{u}$ experimental ultimate load;

$\Delta_{2}$ cracking load of the tested beams / cracking load of beam $\mathrm{B}_{1}$;

$\Delta_{3}$ experimental ultimate loads/theoretical ultimate loads calculated based on equation 8 , and;

$\Delta_{4}$ experimental ultimate load / experimental ultimate load of beam $B_{2}$.

The theoretical shear load of the tested beams was estimated by using equation of ECCS 203 [5], as follows:

$$
V_{u}=\frac{1}{3}\left[2+\frac{0.4 L_{n}}{d}\right]\left(0.70 \sqrt{\frac{f_{c u}}{\gamma_{c}}}\right) b d
$$

Where: $L_{n} \quad$ clear span of the beam;

$f_{c u}$ cube compressive strength in $\mathrm{N} / \mathrm{mm}^{2}$, and;

$\gamma_{c}$ material reduction factor for concrete strength.

Taking into account the shear span to depth ratio equals to 1.50 because the tested beams were short beams, the ultimate shear load estimated by equation (7) was 31.67 ton. Also the ultimate flexural load was estimated for the tested beams by using Egyptian code ECCS 203, [5] and it is equal to 34.09 ton. The experimental loads were higher than the theoretical loads; the maximum increasing was $54 \%$ for beam $\mathrm{B}_{10}$ that provided with $6 \Phi 10$ side bars in three rows. The comparison between the experimental ultimate load of beam $B_{2}$ reference beam, (without side bars), and beam $B_{10}$, showed that the ultimate load is increased by $35.0 \%$. This is because after cracking the side bars strengthen the two struts and the tensile tie formed in the beams when the side bars distributed in three rows along the side face of the beam. 


\section{DEFLECTION}

Figures $7 \mathbf{a}$ to $\mathbf{7 j}$ show the relation between the applied load and the recorded deflection at position of maximum deflection, (mid span section), while in Table 5 the maximum values of deflection at $90 \%$ ultimate load are presented for all tested beams. Generally the repeated loading increases the deflection of the beams because the repeated loading reduces the effectiveness of bond in transferring stresses from steel to concrete causing secondary cracks to form.

From investigation of these figures it is clear that the flexural stiffness increases as the side bars arranged in several rows; (Fig. 7d, 7e and 7j); or located in one row near the tension steel; (Fig. 7f). When the side bars were distributed in several rows; the ductility of the beam was increased. Usually the crack numbers and maximum deflection increased as a result of increasing the ductility.

Table 5: Maximum deformations of the tested beams.

\begin{tabular}{|c|c|c|c|c|}
\hline Beam No. & $\delta_{u} m m$ & $\varepsilon_{s \times 10^{-5}}$ & $\mathcal{E}_{c \times 10^{-5}}$ & $\mathcal{E}_{S S \times 10^{-5}}$ \\
\hline$B_{1}$ & 6.96 & 176 & 91 & - \\
\hline$B_{2}$ & 7.86 & 184 & 98 & - \\
\hline$B_{3}$ & 6.76 & 196 & 81 & 20 \\
\hline$B_{4}$ & 4.86 & 149 & 75 & 112 \\
\hline$B_{5}$ & 4.99 & 156 & 93 & 118 \\
\hline$B_{6}$ & 4.75 & 141 & 90 & 127 \\
\hline$B_{7}$ & 4.41 & 134 & - & 60 \\
\hline$B_{8}$ & 4.63 & 152 & 224 & 45 \\
\hline$B_{9}$ & 4.50 & 187 & 106 & 38 \\
\hline$B_{10}$ & 4.96 & 140 & 90 & 119 \\
\hline
\end{tabular}

Where: $\delta_{u}$ maximum deflection at $90 \%$ of the ultimate load;

$\varepsilon_{s} \quad$ maximum induced strain in main steel at $90 \%$ of the ultimate load;

$\varepsilon_{c} \quad$ maximum induced strain in concrete at $90 \%$ of the ultimate load;

$\varepsilon_{s s} \quad$ maximum induced strain in side bars, (in nearest row to tension steel in case of using more than one row), at $90 \%$ of the ultimate load;

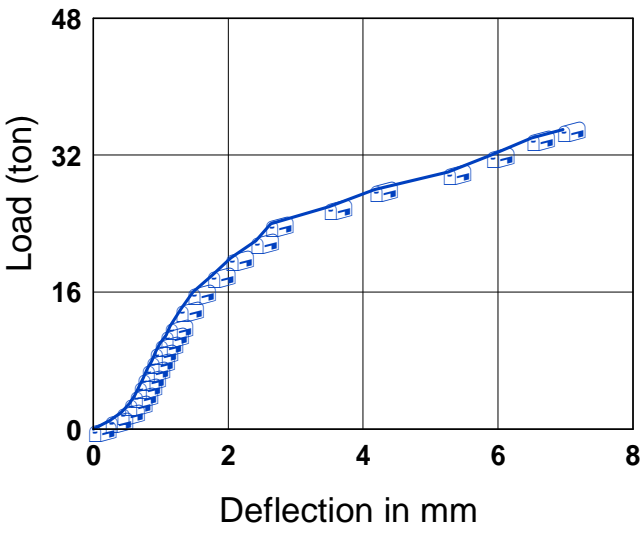

Fig. 7a: Relation between applied load and deflection at mid span for beam $B_{1}$.

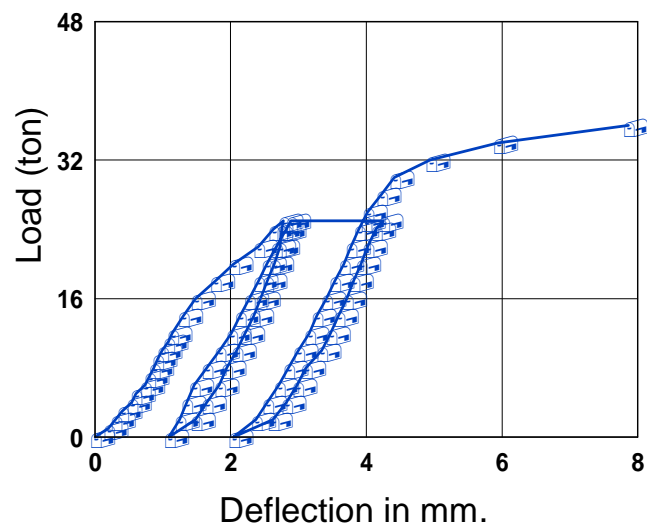

Fig. 7b: Relation between applied load and deflection at mid span for beam $\mathrm{B}_{2}$. 


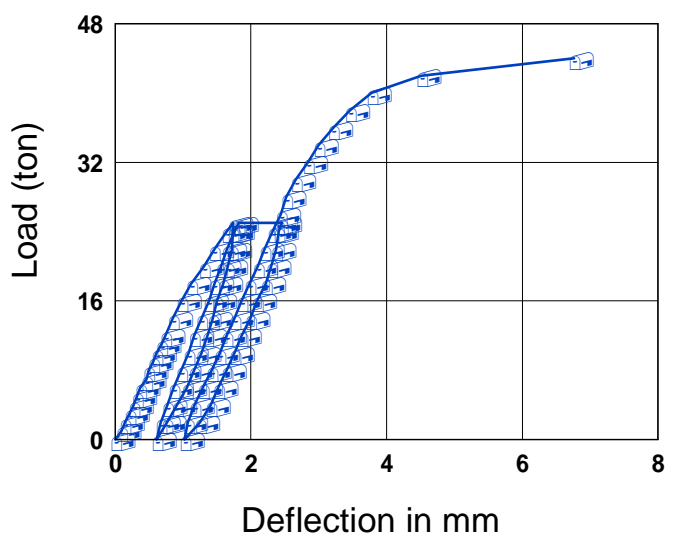

Fig. 7c: Relation between applied load and deflection at mid span for beam $\mathrm{B}_{3}$.

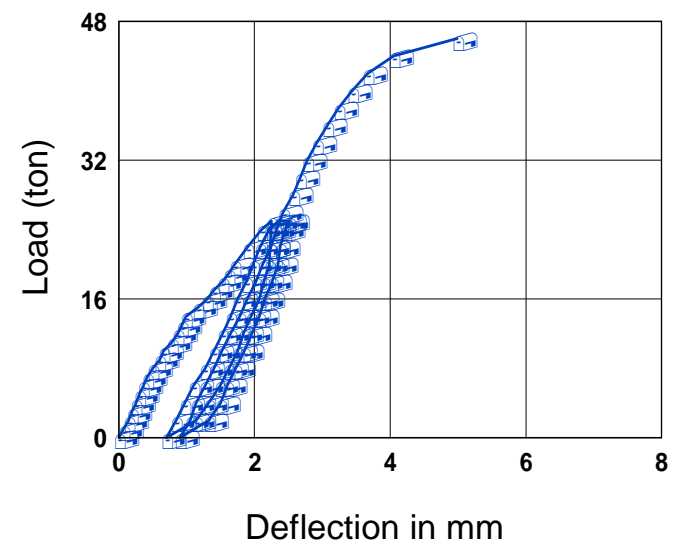

Fig. 7e: Relation between applied load and deflection at mid span for beam $\mathrm{B}_{5}$.

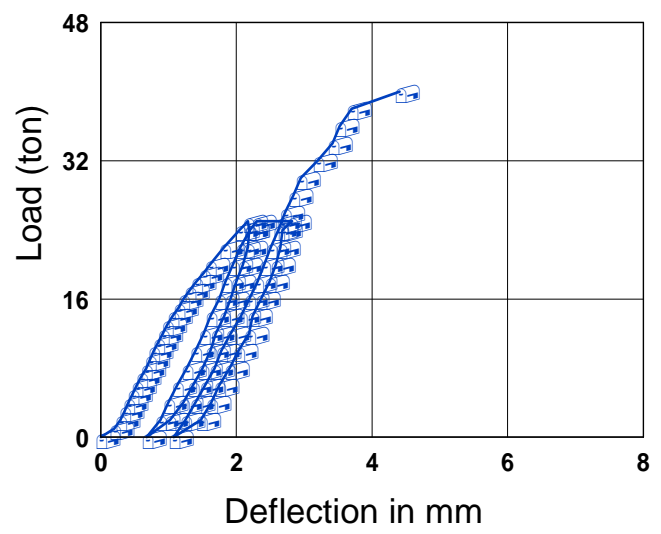

Fig. 7g: Relation between applied load and deflection at mid span for beam $B_{7}$.

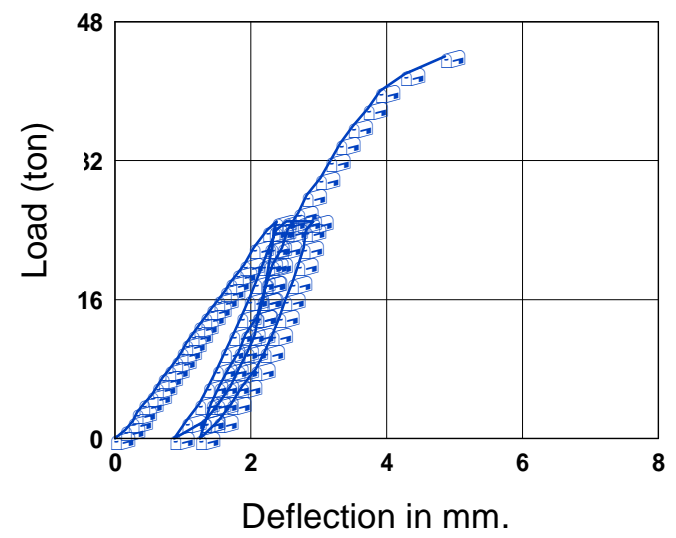

Fig. 7d: Relation between applied load and deflection at mid span for beam $B_{4}$.

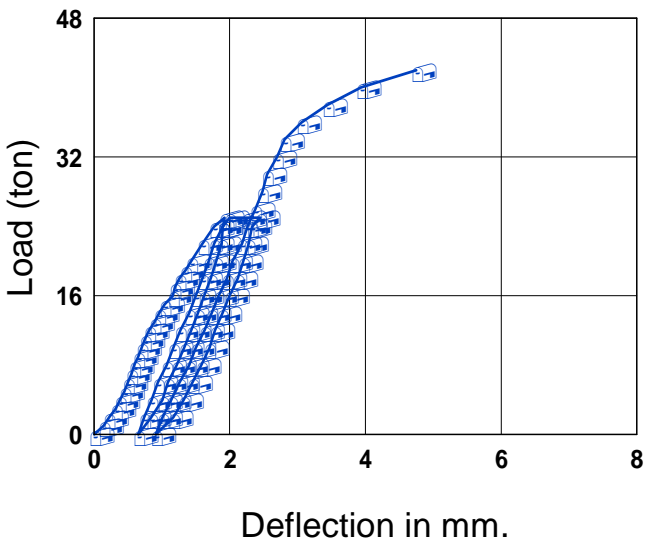

Fig. 7f: Relation between applied load and deflection at mid span for beam $B_{6}$.

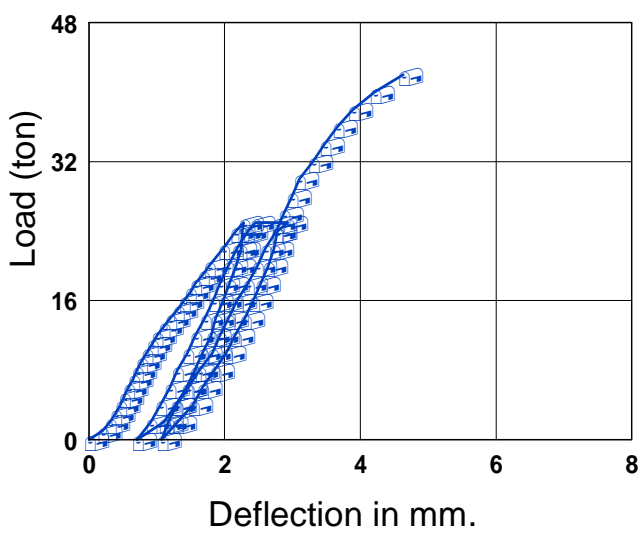

Fig. 7h: Relation between applied load and deflection at mid span for beam $B_{8}$. 


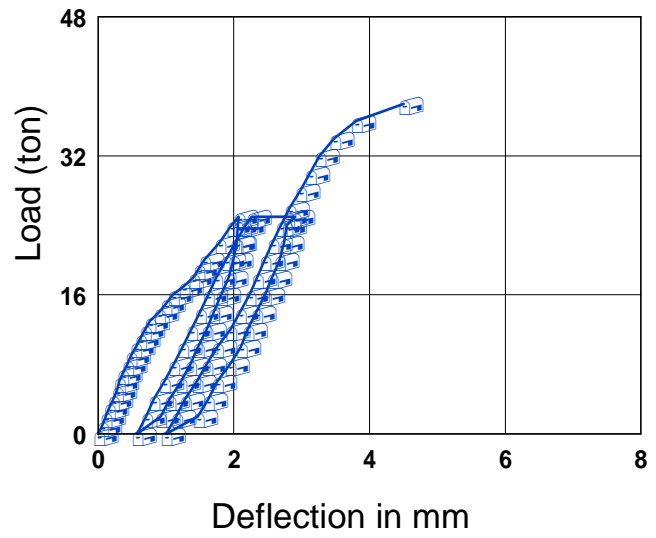

Fig. 7i: Relation between applied load and deflection at mid span for beam $B_{9}$.

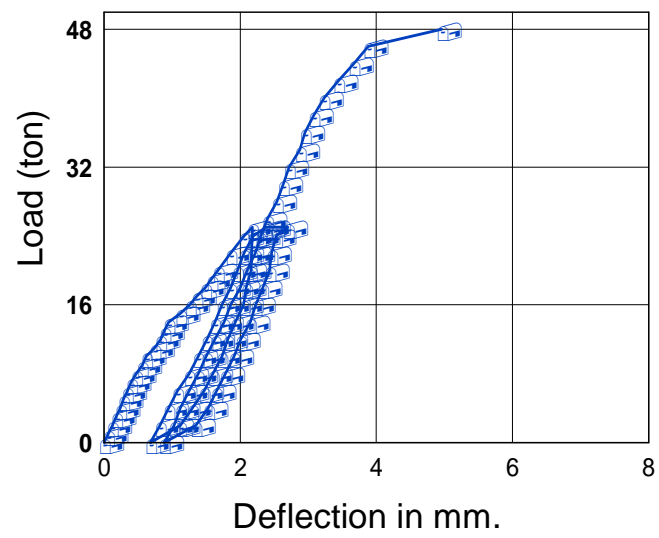

Fig. 7j: Relation between applied load and deflection at mid span for beam $B_{10}$.

\section{STRAINS}

In Figs. $\mathbf{8 a}$ to $\mathbf{8} \mathbf{d}$ the induced strain in tension steel were plotted versus the applied load for beams $B_{1}, B_{3}, B_{5}$ and $B_{6}$. Also the repeated loading has slightly affected the induced steel strain compared with static loading. The induced strain in tension steel increased when the side bars were arranged in several rows, $\left(\right.$ Beam $\left.B_{5}\right)$, or positioned in one row near the tension steel, $\left(\right.$ Beam $\mathrm{B}_{6}$ ). This because the side bars lies in the tension zone and sharing in resistance of the induced tension stress and hence improving the ductility of the beams. In another hand, when the beams provided with side bars in several rows or in one row near the tension steel the ultimate loads were higher than other beams. When the side bars displaced upwards to the compression zone the maximum steel strain was decreased.

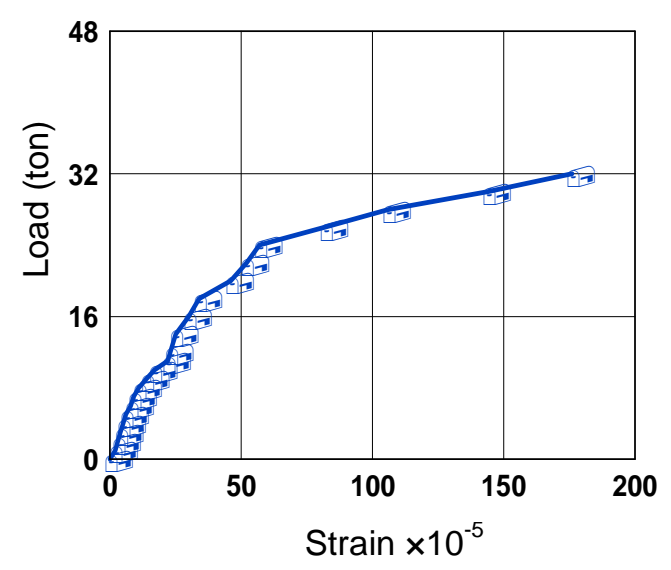

Fig. 8a: Induced steel strain in tension steel of beam $B_{1}$.

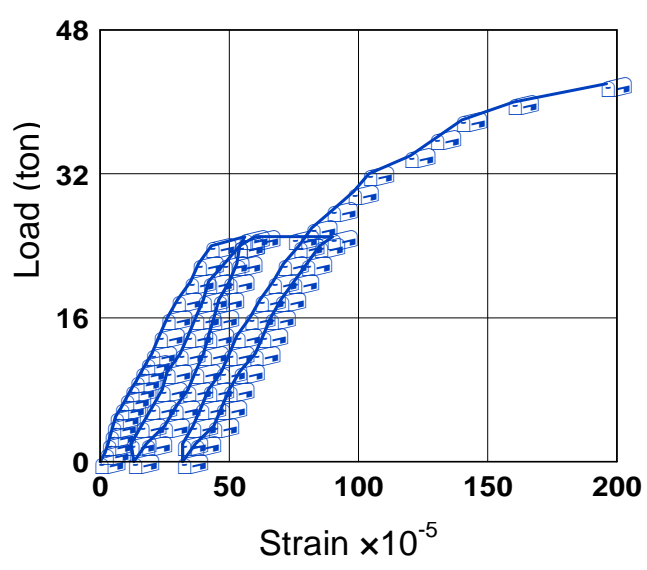

Fig. 8b: Induced steel strain in tension steel of beam $B_{3}$. 


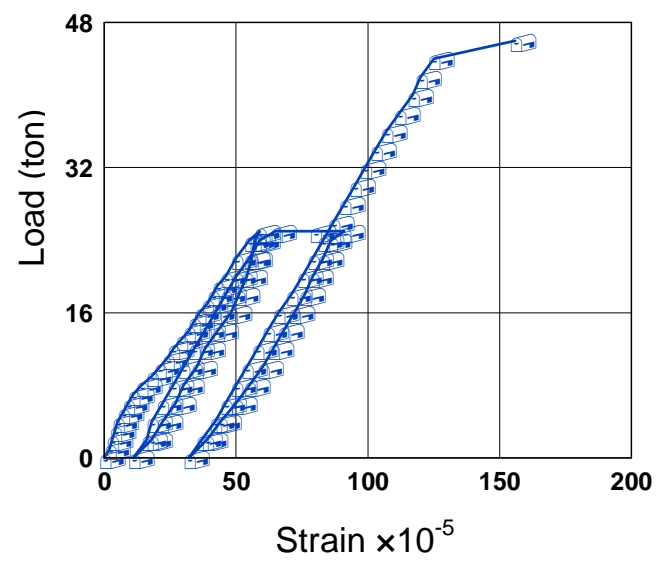

Fig. 8c: Induced steel strain in tension steel of beam $B_{5}$.

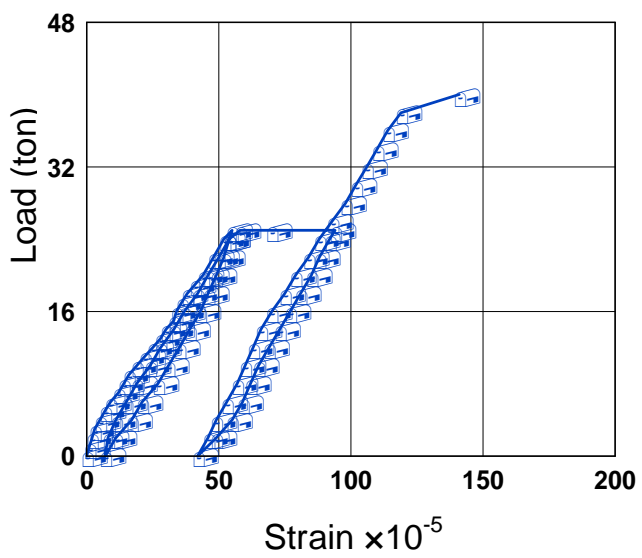

Fig. 8d: Induced steel strain in tension steel of beam $B_{6}$.

At failure the measured induced strain in side bars of beams $\mathrm{B}_{4}, \mathrm{~B}_{5}, \mathrm{~B}_{6}$ and $\mathrm{B}_{10}$ reached almost the yield point of the used steel. The measured induced strain in side bars of beam $B_{9}$ that provided with side bars in one row at $0.80 \mathrm{~d}$ from tension steel was compression in the beginning of loading up to certain limit. After that the measured strain was tension, this means that the side bars lies in compression zone up to certain limit of loading and due to up warding of neutral axis the induced strain become tension strain, see Fig. $8 \mathbf{f}$.

The maximum strain induced in concrete increases when the side bars were arranged in several rows also, (beam $\mathrm{B}_{5}$ ) or in one row displaced towards the compression zone, beam $\mathrm{B}_{8}$. This is due to the distribution of side bars along the depth which is usually improves the stiffness and ductility of the beams as well as strengthens the compression zone, see Figs. $\mathbf{8 g}$ and $\mathbf{8 h}$.

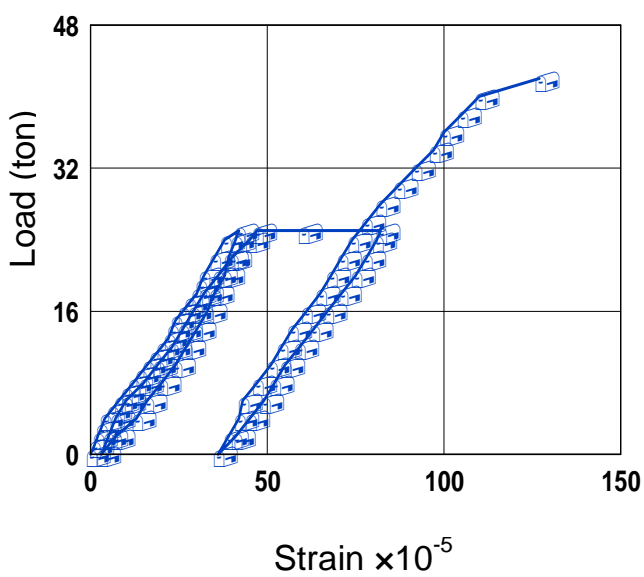

Fig. 8e: Induced steel strain in Side bars of beam $B_{6}$.

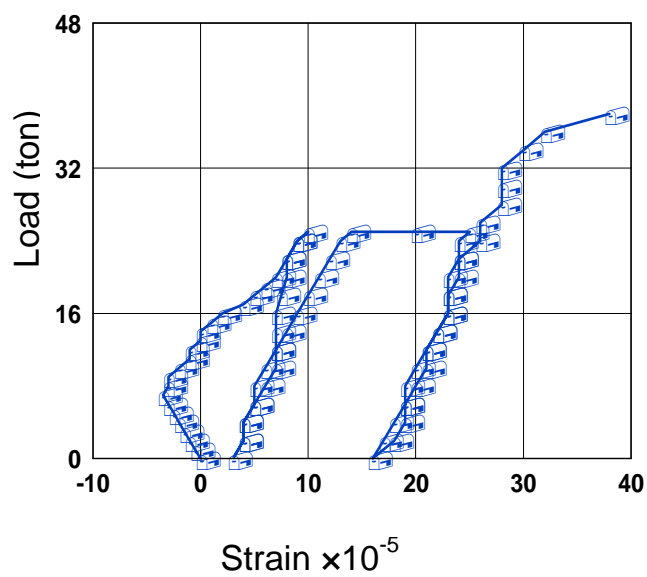

Fig. 8f: Induced steel strain in side bars of beam $B_{9}$. 


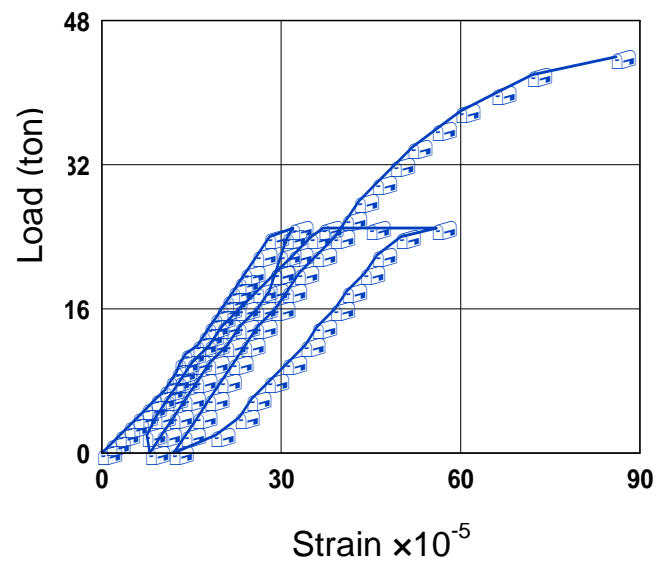

Fig. 8g: Induced concrete strain in beam $\mathrm{B}_{5}$.

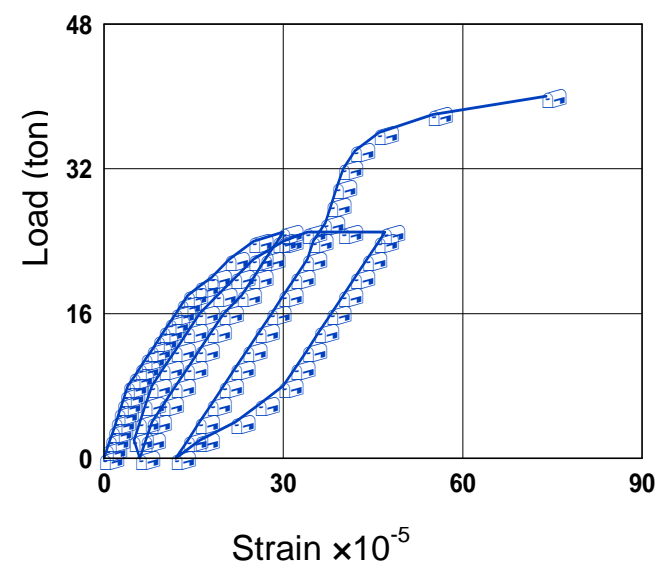

Fig. 8f: Induced concrete strain in beam $\mathrm{B}_{6}$.

\section{CONCLUSIONS}

An experimental work was under taken to investigate the effectiveness of arrangement of side bars, their position from tension steel and amount of their area to tension steel on the shear response of short beams failing due to shear stresses and subjected to repeated loading. The following conclusions can be made from the experimental results.

1- There are considerable differences regarding how much side bars reinforcement appropriate. ECCS 203 and DIN 1045, recommended the lowest area of side bars.

2- The repeated loading has a slight effect in the shear strength of the tested beams; meanwhile it has a pronounced effect in their deformations.

3- Providing of side bars to short beams failing due to shear stresses increases the crack numbers however decreases crack widths and their slopes to horizontal. The crack widths for beams provided with side bars were lower than the crack widths of beams without side bars. Using area of side bars equal to five times which recommended in ECCS 203 reduced the crack width to 0.38 times that calculated by ACI code, equation 4 .

4- Arrangement of side bars in several rows along the side face of the beam crosssection is the best situation for positioning to improve both overall load capacity and deformation. The cracking load of beams providing with side bars arranged in three rows was 1.30 times the cracking load of beam providing with side bars arranged in one row at the middle half of beam cross section.

5- After cracking the side bars tends to redistribute the internal forces and hence increasing the shear capacity. The experimental ultimate loads were higher than the theoretical ultimate loads by $49 \%$ and $54 \%$ for beams provided with side bars area equals to three times or five times that recommended in ECCS 203 in three rows, respectively. 
6- The contribution of side bars on shear strength of short large R.C beams was significant effect that it is recommended to be taken into account in designing such beams.

\section{REFERENCE}

[1] Placas A.," Shear Failure of Reinforced Concrete Beams" PhD Thesis, University of London, 1967.

[2] Placas A. and Paul E., "Shear Failure of Reinforced Concrete Beams" ACI Journal, 68, 1971, pp.763-773.

[3] Frantz G.C. and Breen J.E. " Cracking of Side Faces of Large R.C. Beams", ACI Journal, Proceedings Vol. 77, No. 5, Sept.-Oct. 1980, pp. 307-313.

[4] Perry Adebar and J. Van Leeuwen "Side-Face Reinforcement for Flexural and Diagonal Cracking in large beams” A CI Structural Journal, Sept.-Oct. 1999, pp 698-704.

[5] Egyptian Code for Design and Construction of R.C. Structures second edition, 2003.

[6] ACI Committee 318, Building Code Requirements for R.C. (ACI-89), American Concrete Institute, Detroit, 1995.

[7] Frantz G.C. and Breen J.E. "Design Proposal for Side Face Crack Control Reinforcement for Large R.C. Beams", Concrete International Journal, Proceedings Vol. 2, No. 10, Oct. 1980, pp. 29- 34.

[8] CP114, Code of Practice for the Structural use of Concrete British Standard Institute, Nov., 1972.

[9] Zainab E. Abd El-Shafy, Yehia A. Hassanean, Mohamed M. Ahmed and A. Megahid Ahmed "Contribution of Shrinkage Bars in Flexural Strength of R.C. Beams under Static Loading“, Bulletin of the Faculty of Engineering, Assiut University, Vol. 28, No. 2, May 2000.

[10] Vecchio, F.J and Collins, M.P. "The Modified Compression Field Theory for Reinforced Concrete Elements Subjected to Shear", ACI Journal Proceedings Vol. 83, No. 2, Mar.-Apr. 1986, pp. 219-231.

[11] Troxell G.E, Davis R.E. and Raphael J.M. , "Long -Term Creep and Shrinkage Tests of Plain and R.C.” Proceedings ASTM Vol. 58, 1958.

[12] James G. Macgregor "Reinforced Concrete Mechanics and Design" Prentice Hall, Inc., New Jersey, U. S. A., 1988.

[13] F. Bljuger "Cracking resistance of Concrete Members in Bending”, ACI Journal Proceedings Vol. 83, No. 3, July/August 1986, pp. 467-472.

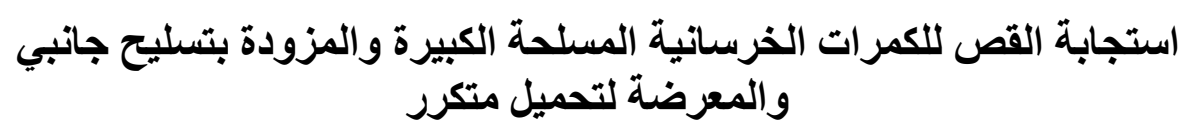

تسبب الثروخ في العناصر الخرسانية المسلحة أضرار بالغة حيث أنها تقلل من دوامية العنصر

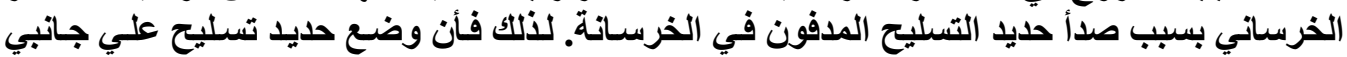

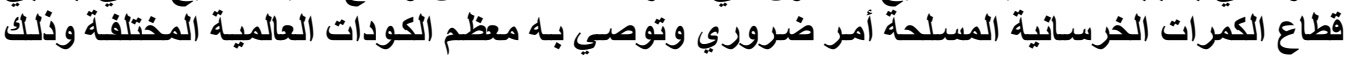
بغرض تقليل عروض الثروخ الناجمة سواء من اجهادات الانحناء أو اجهادات القصات العصات 
يـهدف هذا البحث إلـي دراسـة تـأثير وجـود الحديد الجـانبي علي اسـتجابة القص للكمرات

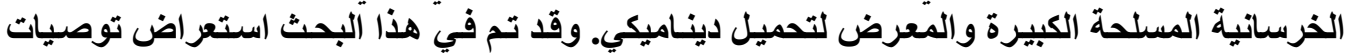

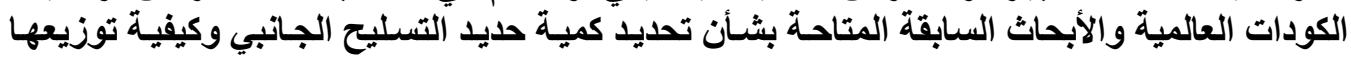

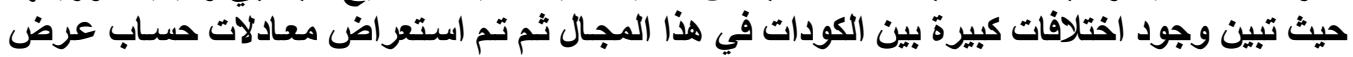

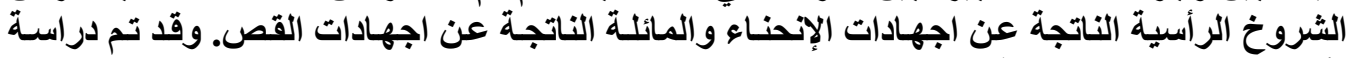

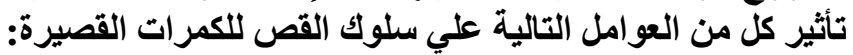

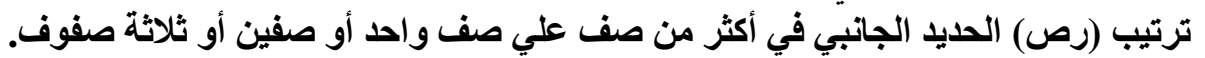

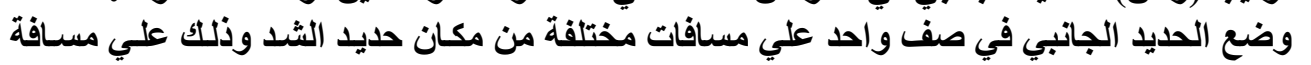

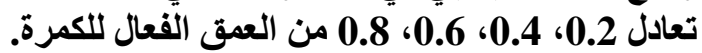

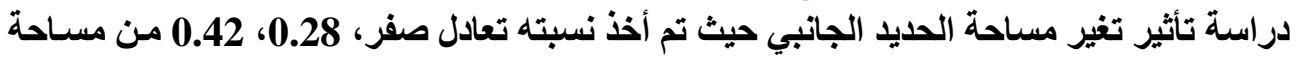
حديد الشد . درالير

لهذا الغرض تم إعداد وتجهيز وصب عشرة كمرات ذات بحر فعال 194 سم وبحر قص إلي

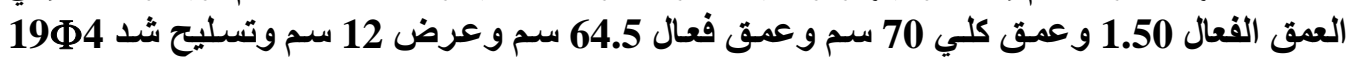

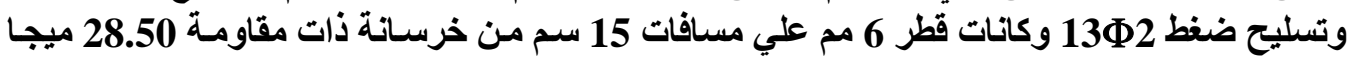

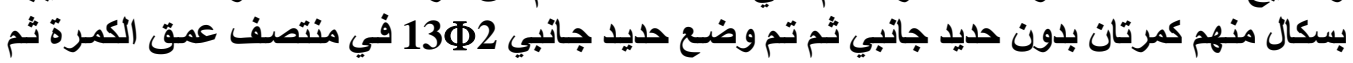

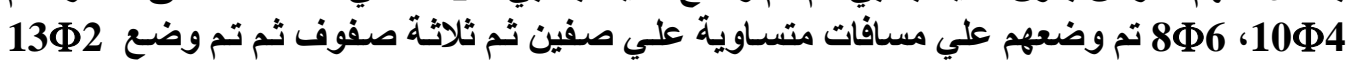

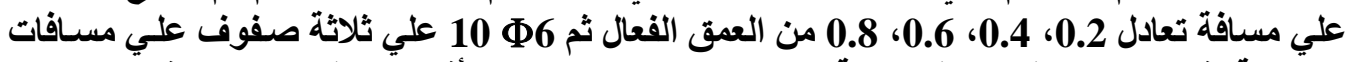

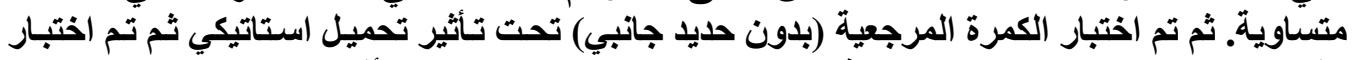

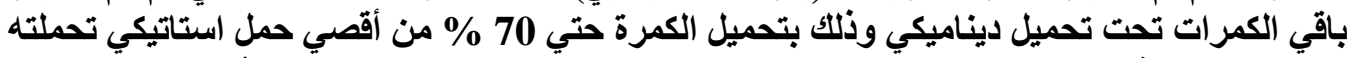

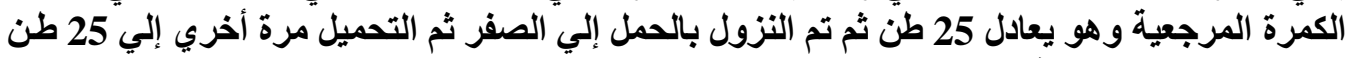

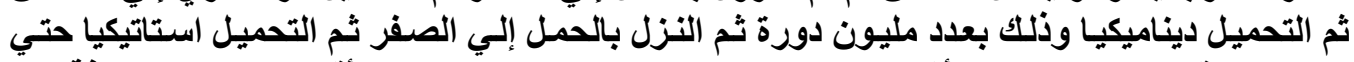

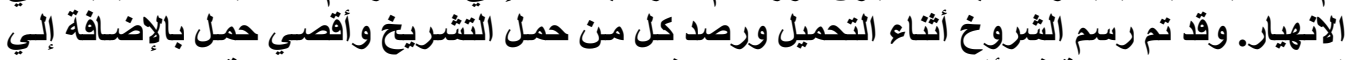

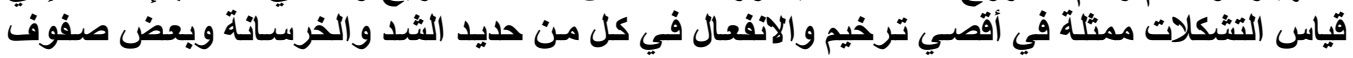

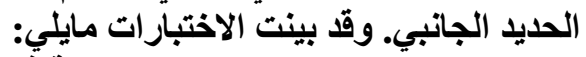

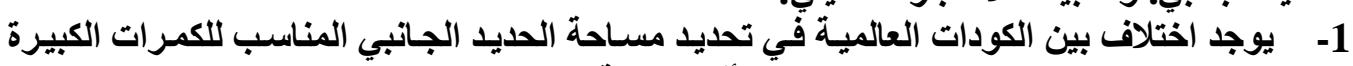

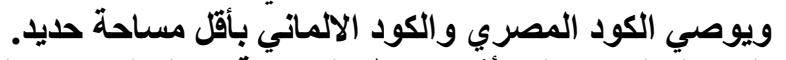

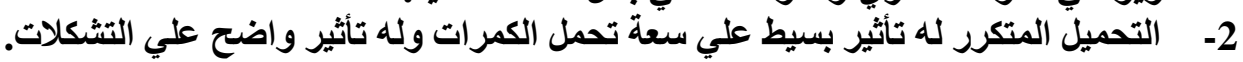

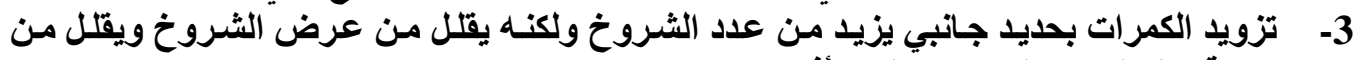

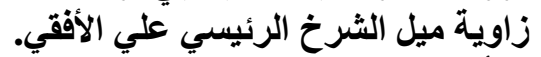

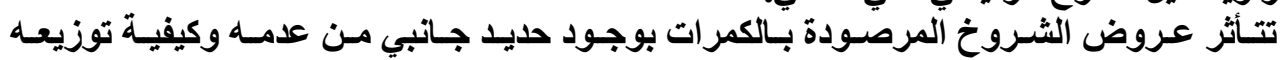

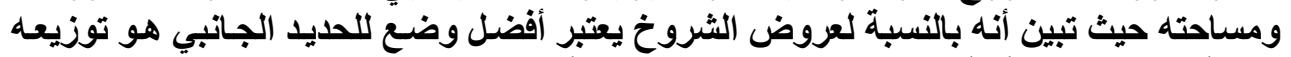

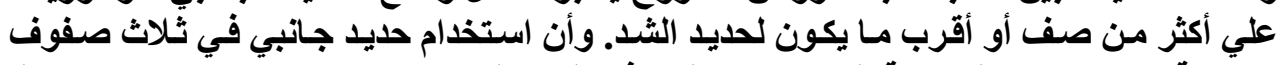

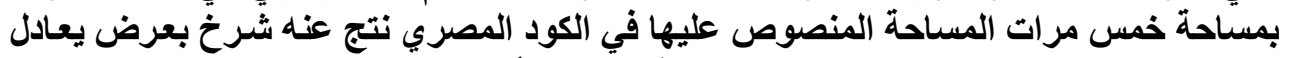

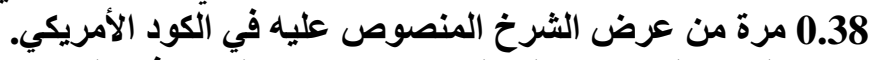

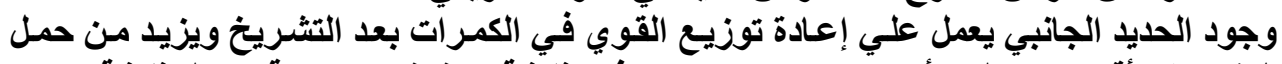

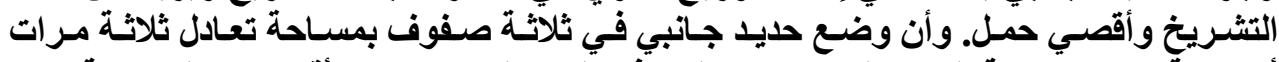

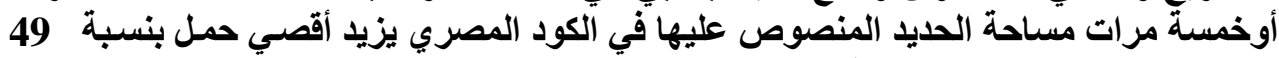

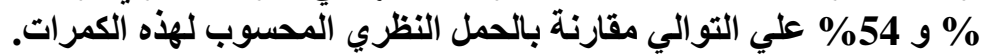

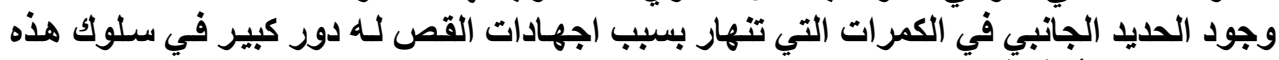
الكمرات يمكن أخذه في الاعتبار عند التّميم. التيم. 